\title{
FIGURATIVE LANGUAGE ENTRY-LEVEL ANALYSIS ON ROBERT FROST'S A MINOR BIRD
}

\author{
Gabriel C. Sudibyo \\ Indonesian Institute of Arts Yogyakarta
}

\begin{abstract}
Poem employs a variety of aesthetic devices varying from rhythm, meter, and on textual literary content: figurative language. Through the usage of figurative language, a short poem is capable to deliver more in-depth meaning in each word. In the poem A Minor Bird by Robert Frost, the poet employs symbols and imagery as the most prominent figurative language device. Hence this paper aims to identify these devices and further explains it as a poem breakdown analysis in hope to enlighten readers' perception and understanding against entry-level poem analysis. The method used in this research is library research and literature review.
\end{abstract}

Key words: Robert Frost, figurative language, poem analysis

\section{Introduction}

Literature has many kinds of forms, and poem is just one of them. According to Laurence Perrine in Sound and Sense: An Introduction to Poetry (1956, p. 3), "poetry might be defined as a kind of language that says more intensely than does ordinary language". Though poem is short in words, yet a good poem is capable in telling as much as a long novel. Poem tells not only about a story, but also about the feel and the world surrounds it. Readers are invited to the world and atmosphere inside the poem in much intimate way than any other literature can offer in such a few words.

In the world of poetry, Robert Frost is a famous figure known of his works. $A$ Minor Bird, although released many years ago, is an example in how he employs his distinct uses of figurative language. In effort to do an entry-level poem analysis, the writer chooses to analyze A Minor Bird poem as it is denotative enough yet uses a lot of imageries that can be delved further. In analyzing a poem, the general problem arises is to identify the figurative language, to categorize them into poem intrinsic elements, and finally to explain of the diction's usage and meaning.
This paper aims to explain the symbol and imagery within the poem $A$ Minor Bird by Robert Frost. This poem resounds more in recent days with the hints of natural environment and marginalized society's cry for judgment, hence it is interesting to dissect more into the figurative language this poem has. To ensure the focus of the analysis, this discussion will be limited to only three most prominent imageries, which are auditory, kinesthetic, and organic imagery. The analysis done is limited to only in entry-level poem analysis as it is aimed to explain and introduce to lay readers about the basic of poem closereading.

\section{Previous Study}

A Minor Bird has been analyzed extensively and the articles about such analysis can be found both in online and offline sources. It is exactly because the poem has been exhausted and exploited in many points and various depths that the writer chooses to do an entry-level analysis against the poem, so that the readers may find this analysis as an introductory article that may leads to other in-depth analysis. 


\section{Theory of Symbolism and Imagery}

The analysis relies heavily on Perrine's definitions and kinds of figurative language explained extensively in Sound and Sense.

\section{Symbolism}

Perrine states in Sound and Sense:

An Introduction to Poetry that "symbol maybe roughly defined as something that means more than what it is" (1956). As an addition, Morner and Rausch also explain that "a symbol is usually something concrete - an object, a place, a character, an action that stands for or suggests something abstract" (1998). From both statements, it can be concluded that symbol is used mainly for abstract things that is symbolized as something concrete which have both connotation and denotation meaning.

2. Imagery

Also from Perrine, he writes that imagery "may be defined as the representation through language of sense experience" (1956). Although there are seven kinds of imagery, e.g. visual, auditory, kinesthetic, gustatory, olfactory, organic imagery, and tactile imagery (Perrine, 1956), the writer will only discuss about three kinds of imagery.

2.1. Auditory

Auditory is mainly the imagery of sound. Sounds that usually heard from ears are mentioned and described in words by the poet. It will be discussed further how the poet represents the sounds in the poem. (Pradopo, 1995)

\subsection{Kinesthetic}

Kinesthetic is imagery produced by form of movement, it might be motions by living being or merely muscles tension. The writer will explain about the gesture which the poet had written and what it represents. (Pradopo, 1995)

2.3. Organic

Organic Imagery is coming from internal sensation, like hunger, thirst, or nausea. In the discussion, the writer will talk about the guilty and annoyed feeling that is apparent on the poem.

\section{Method and Data}

This paper was made by using library research and theoretical approach against the figurative language by studying the text with the suitable references. The writer needs to do close-reading to accurately identify which dictions belong to symbolism, imagery, or other figurative language.

It is also required to include the poem itself within the text body to ensure the readers' ability to fully comprehend the passage and self-compare the explanations given at discussion. Below is the text as data itself: Robert Frost's A Minor Bird.

\section{"A Minor Bird}

I have wished a bird would fly away, And not sing by my house all day;

Have clapped my hands at him from the door When it seemed as if I could bear no more.

The fault must partly have been in me. The bird was not to blame for his key.

And of course there must be something wrong In wanting to silence any song."

\section{Symbolism}

From the poem, it mainly tells about how a human was annoyed because of the bird keep on singing on his house. The writer believes that this "bird" is actually a symbol of something else. There are two main symbols in the poem and both of them are included in the title "A Minor Bird"

1. Bird

In this poem, the bird represents the nature, and their songs represent nature's attitudes toward humanity. Bird provides a voice for the natural world to communicate with humans. But their songs are the only 
way to communicate toward the human world, and as a part of nature, bird has a right to their song, even if it annoys or distresses the listeners. The poet tries to make the reader feel, how this person had tried to go against the nature, which is by trying to silence the bird, but he realized that it could not be done and soon he felt guilty in doing so.

In A Minor Bird, the speaker eventually realizes that all songs must continue to exist, whether those songs are found in nature, as with birds, or as with poems. With that point, it can also be assumed that the bird and the bird's song are to symbolize poetry. Bird becomes a medium which to comment on the efficiency of poetry as a tool of emotional expressions.

The bird can also be assumed to symbolize actual life or reality. The speaker, the human, was obsessed with his personal life. As people have become more selfish, they have come to a state where they find it hard to endure activities of one another.

2. Minor

"Minor" is a symbol of helplessness. In the poem, the speaker did not like this small bird because even though he tried to make him go away, the bird just kept on singing in his house. With "minor" to symbolize helplessness, the poet was likely to mean that in this world, there is a sense of helplessness, that even though it is already helpless, the speaker in the poem still try to oppress it even more by swatting it away.

"Minor" also represents a minority. The minority can refer to the society, community, or other thing within population. From this poem, it can be said that this one bird was opposing a much bigger opponent, both in power and ability, which is symbolized as a human. The writer believes that Robert Frost was trying to illustrate, through symbols, how the minority people were against the majority who oppressed them.

\section{Imagery}

1. Auditory

"The fault must partly have been in me.

The bird was not to blame for his key.

And of course there must be something wrong

In wanting to silence any song."

It is clear that the speaker heard the "song" from the bird by the "key" or tone that he sang all day. This can only indicate that the speaker had heard all of this through his auditory sense.

2. Kinesthetic

"Have clapped my hands at him from the door

When it seemed as if I could bear no more."

Obviously, by "clapping my hands" it is included as kinesthetic imagery, which is showing that there is a movement happened in the poem, even though maybe just a simple act.

3. Organic Imagery

3.1. Annoyed Feeling

"I have wished a bird would fly away, And not sing by my house all day;

Have clapped my hands at him from the door

When it seemed as if I could bear no more."

Even from the first stanza, the poet already gives a hint that what he wanted for his comfort was way out of human's capabilities. "wished" tells that he is not capable in doing anything except for only wishing so that the bird would fly. He is powerless in front of the bird, which represent the nature. And it is apparent how he felt so annoyed because of this until he could not say anything else except that "I could bear no more".

\subsection{Guilty Feeling}


"The fault must partly have been in me. The bird was not to blame for his key.

And of course there must be something wrong

In wanting to silence any song."

Near the last stanza, the speaker became more and more solemn that he had ever been at the beginning. He started to question himself whether the one was wrong was actually him. He pondered at the thought of why wouldn't the bird stop singing and finally drew a conclusion that there must be "something wrong".

He realized that even that bird was quite tiny compared to him, that bird also had his own right to keep on singing. He felt very guilty of how thoughtless he had been and that feeling remained until the last stanza.

\section{Conclusion}

A Minor Bird mainly tells a simple small conflict between humanity, or between humanity and nature. The selfish speaker started very roughly by hating the innocent bird and tried anything he could to silence the bird. Even from the short poem, it is obvious how the speaker undergone a change in his way of thinking, or even behavior. He became much wiser than at the beginning and much calmer.

While this poem can be taken as how the minority voiced their opinions against the much greater force above them, yet it can also means how meaningless of a human to oppose against nature. The poet succeeded in creating the ambiguity surrounds the poem and managed to tell the moral values of both meaning.

The most powerful message that Frost delivered in this poem is that it is wrong to try to silence anyone's opinions and beliefs. As if the poet clearly said that no matter how small or powerless you were, your opinion and rights have its own value and worth.

\section{References}

Morner, K \& Rausch, R. (1998). NTC's Dictionary of Literary Terms. Illinois: NTC Publishing Group:

Perrine, L. (1956). Sound and Sense: An Introduction to Poetry. Orlando: Harcourt Brace Company.

Pradopo, R. J. (1995). Pengkajian Puisi Analisis: Strata Norma dan Analisis Struktural dan Semiotik. Yogyakarta: Gadjah Mada University Press. 